\title{
Stability-indicating RP-HPLC method development and validation for simultaneous estimation of bisoprolol fumarate and amlodipine besylate in bulk and in tablet dosage form
}

\author{
Rameshwar Bhausaheb Gholve*(D), Sanjay Sudhakar Pekamwar (D), Tukaram Mohanrao Kalyankar (D) \\ Department of Pharmaceutical Chemistry, School of Pharmacy, Swami Ramanand Teerth Marathwada University, Nanded, India.
}

\section{ARTICLE INFO \\ Received on: 04/06/2021 \\ Accepted on: 21/07/2021 \\ Available Online: 05/12/2021}

\section{Key words:}

RP-HPLC, bisoprolol,

amlodipine, forced

degradation, solution

stability, validation.

\begin{abstract}
A novel chromatographic method has been developed with a stability-indicating feature for simultaneous estimation of bisoprolol fumarate (BSL) and amlodipine besylate (AMD) in bulk and in tablet dosage form with minimized drug extraction steps. The chromatographic analysis was executed by the isocratic elution mode using Oyster ODS3 (150 $\times$ $4.6 \mathrm{~mm}, 5 \mu \mathrm{m}$ ) column (Merck \& Co.) as the stationary phase at ambient temperature (about $25^{\circ} \mathrm{C}$ ) with $1.0 \mathrm{ml} / \mathrm{minute}$ flow rate and $20 \mathrm{mM}$ phosphate buffer with $\mathrm{pH} 2.5$ (adjusted by $5 \%$ orthophosphoric acid):methanol:acetonitrile $(42: 29: 29, \mathrm{v} / \mathrm{v} / \mathrm{v})$ as eluents at a wavelength of $230 \mathrm{~nm}$. The retention time was found to be 2.543 and 4.883 minutes for bisoprolol and amlodipine, respectively. The method was found to be linear in the concentration range of 60.08$140.19 \mu \mathrm{g} / \mathrm{ml}$ for BSL and $59.73-139.37 \mu \mathrm{g} / \mathrm{ml}$ for amlodipine with squared correlation coefficient $\left(R^{2}\right)$ of 0.999 in both cases. Individual drug substances and their combination drug product were exposed to conditions like acid, alkali, oxidative, thermal, photolytic, and humidity degradation; the degradation peaks were well separated from active analyte peaks. The acid-, alkali-, thermal-, and photolytic-induced stress studies signified the formation of a variety of degradants. Hence, it is recommended that BSL and AMD drug substances, as well as drug products, should be stored in tightly closed container protected from light and heat. The method was validated for specificity, linearity, quantitation limit, detection limit, accuracy, precision, robustness, and solution stability as per International Conference on Hormonization (ICH) guidelines and effectively used for regular analysis.
\end{abstract}

\section{INTRODUCTION}

Bisoprolol fumarate (BSL) is chemically known as (2RS)-1-[4-[[2-(1-methylethoxy)ethoxy]methyl]phenoxy][(1-methylethyl)amino]propan-2-ol fumarate (Fig. 1a), which is a white or almost white powder and is official in the United State Pharmacopeia, European Pharmacopeia, and Indian Pharmacopoeia. It is categorized as a $\beta$-adrenoceptor antagonist (European Pharmacopoeia 10.0, 2020; Indian Pharmacopoeia, 2018; United State Pharmacopeia, 2020).

\section{"Corresponding Author}

Rameshwar Bhausaheb Gholve, Department of Pharmaceutical Chemistry, School of Pharmacy, Swami Ramanand Teerth Marathwada University, Nanded, India.E-mail address: Rameshwar.Gholve@hotmail.com
Amlodipine besylate (AMD) is chemically known as 3-ethyl 5-methyl (4RS)-2-[(2-aminoethoxy)methyl]-4-(2chlorophenyl)-6-methyl-1,4-dihydropyridine-3,5-dicarboxylate benzenesulfonate (Fig. 1b), which is white or almost white powder and is official in the United State Pharmacopeia, European Pharmacopeia, and Indian Pharmacopoeia. It is a calcium channel blocker categorized as antihypertensive and antianginal agents (European Pharmacopoeia 10.0, 2020; Indian Pharmacopoeia, 2018; United State Pharmacopeia, 2020).

Individually or in combination, BSL and AMD are widely used as antihypertensive drugs and both the drugs have different and complementary mechanisms of actions to decrease blood pressure. The combination therapy of BSL and AMD shows an additive effect in blood pressure control, resulting in reduced risk of cardiovascular events. Hence, the fixed dose combination of BSL and AMD is more effective and significantly better than 
<smiles>CCOC(=O)C1=C(COCCN)NC(C)=C(C(=O)OC)C1c1ccccc1Cl</smiles>

Figure 1. Structure of (a) BSL and (b) AMD.

monotherapy as the side effects decrease and the compliance of patient increases (Hostalek and Koch, 2016).

To know the inherent stability characteristics of active component(s), stress testing needs to be carried out (ICH, 2003). Related substances and/or impurities are generated during the manufacturing process and/or degradation products from inappropriate storage or handling of material or as metabolites which can be active, inactive, or even toxic, and significantly affects the results with respect to quality, safety, and efficacy. Good stability-indicating methods having the capability to resolve degradation products or impurities significantly from the active components (Alsante et al., 2011; Aubry et al., 2009; Blessy et al., 2014; Thakur et al., 2015).

Nowadays, several analytical reports employ the validated reverse phase high-performance liquid chromatography due to the advantage of it being efficient, easy to use, and accurate, as well as its ability to provide the best separation of analytes. Also, high performance liquid chromatography (HPLC) equipped with different types of detectors, like Ultra-Violet (UV)/ Photo-Diode Array (PDA)/ Fluorescence/ Refractive Index (RI)/ Evaporative Light Scattering Detector (ELSD)/ Mass (MS)/ Pulsed Electrochemical Detector (PED)/ Pulsed Amperometric Detector (PAD), have additional advantages in the field of drugs analysis. The HPLC technique is widely used for the determination of drugs in bulk and in pharmaceutical dosage forms, as well as in biological fluids. It is also applicable for developing a stability-indicating method which helps in the selection of appropriate storage conditions (Da Silva Medeiros et al., 2020; Gamal, 2020; Hosny, 2020; Mohammed et al., 2021).

Surveys of the literature show that few methods are reported for the simultaneous estimation of BSL and AMD by HPLC techniques. The available methods have some limitations such as time-consuming procedures, low resolution, and long run time; forced degradation study was carried out on drug substance and on drug product; not for photolytic and humidity stress conditions (Patil et al., 2017); forced degradation study was not carried out (Baokar et al., 2011; Pant and Pal, 2012; Patil et al., 2014), but forced degradation study was carried out only on drug product and not on drug substance and humidity stress condition (Vora and Kadav, 2008). In addition to this, some robustness parameters along with mobile phase preparation, for standard and sample solution stability, need to be analyzed. Therefore, an attempt has been made to execute stress study on both drug substances individually and their combination drug product to develop a validated reverse phase - high performance liquid chromatography (RP-HPLC) method having the stability-indicating feature for the simultaneous estimation of BSL and AMD which is more simple, rapid, sensitive, specific, precise, accurate, and robust.

\section{MATERIALS AND METHODS}

\section{Chemicals/materials}

BSL (Batch no.: 2010005540, Purity: 99.74\%) and AMD (Batch no.: 2010005135, Purity: 99.96\%) pure drug samples were gifted by Unichem Laboratories Ltd., Goa, India. All the chemicals like potassium dihydrogen phosphate (PDP) (Batch no.: H14A/1514/1306/53, Make: SD Fine Chem Ltd., Mumbai, India), acetonitrile (Batch no.: 1092840616, Fischer Scientific India Pvt. Ltd., Mumbai, India), orthophosphoric acid (Batch no.: 2467211117, Make: Research Lab Fine Chem Industries, Mumbai, India), 6\% v/v hydrogen peroxide (Batch no.: MCM-1171, Make: Molychem, Mumbai, India), sodium hydroxide (Batch no.: DH6D662478, Make: Merck, Mumbai, India), hydrochloric acid (Batch no.: CK6C660816, Make: Merck, Mumbai, India), and water were of HPLC grade or equivalent grade were used during the experiments. BSL and amlodipine tablets were $5 / 5 \mathrm{mg}$ $\left(\right.$ CORBIS ${ }^{\circledR}$ AM -5$)$ - each film-coated tablet containing BSL 5
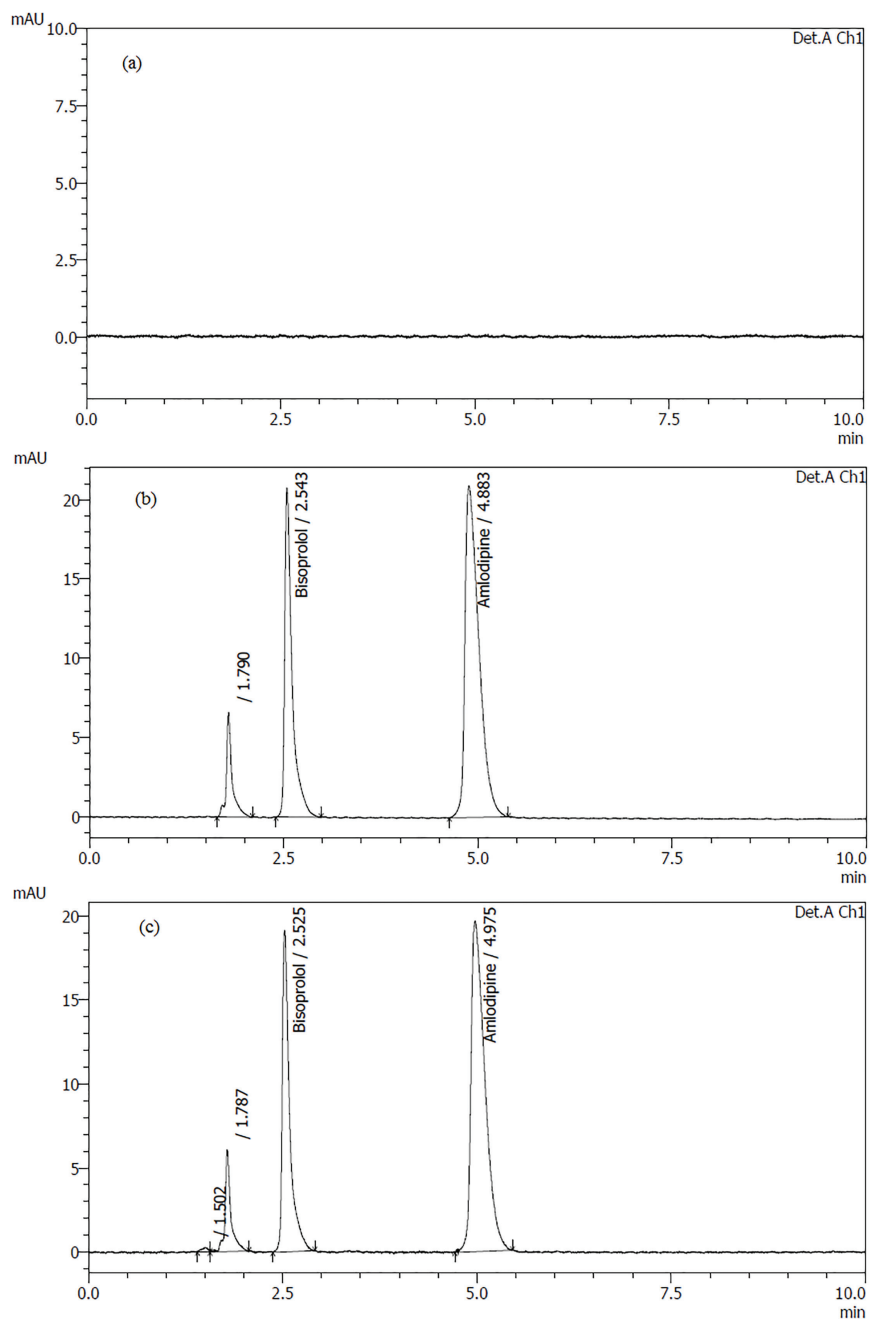

Figure 2. Chromatograms of (a) blank, (b) standard, and (c) sample. 

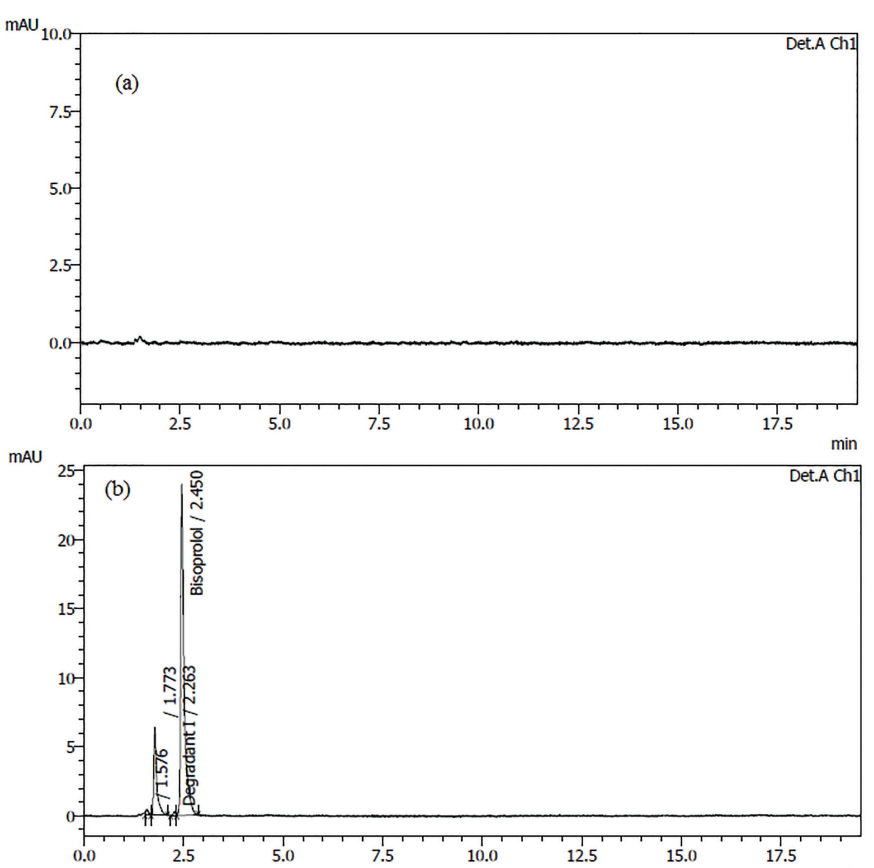

mAU

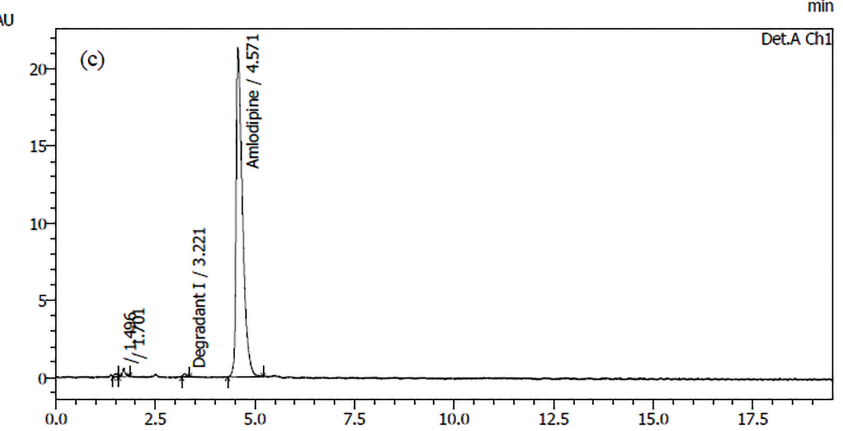

mAU

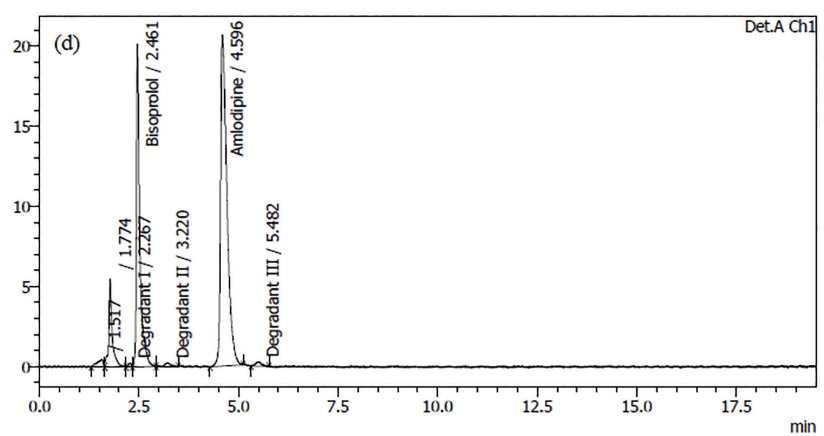

Figure 3. Chromatogram of acid-stressed (a) blank, (b) BSL, (c) AMD, and (d) sample.

$\mathrm{mg}$ and $\mathrm{AMD}$ equivalent to amlodipine $5 \mathrm{mg}$ was procured from a local medical store (Batch no.: 2013406TT, Marketed by: Torrent Pharmaceuticals Ltd., Mehsana, India, Make: Ordain Health Care Global Pvt. Ltd., Kanchipuram, India).

\section{Instruments}

Weighing of the materials was carried out using an analytical weighing balance (Make: Citizon, Model: CY204). A digital ultrasonic cleaner (Make: Labman Scientific Instruments, Model: LMUC-3) was utilized for the sonication. A digital $\mathrm{pH}$ meter (Make: Labtronic Laboratory Instruments, Model: LT49) was employed for the estimation of solution $\mathrm{pH}$. The hot air oven (Make: Bio-Technics India, Model: BTI-29), stability chamber (Make: Labline Stock Centre, Model: GMP), and photostability chamber (Make: S R Lab Instruments India Pvt. Ltd., Model: SRL-PHSC-11-A) were used during the forced degradation study. A refrigerator (Make: LG, Model: GL-A282SPZL) was used during the solution stability study. A water purification system (Make: Analytical Technologies Limited, Model: WPS211) used to collect ultrapure water for the experiment. The method was developed on an Oyster ODS3 $(150 \times 4.6 \mathrm{~mm}, 5 \mu \mathrm{m})$ column (P/N: S670153, Make: Merck \& Co.) connected to a HPLC system (Make: Shimadzu, Model: SCL-10Avp) equipped with a UV detector having rheodyne sample injection port with a $20 \mu \mathrm{l}$ loop. The chromatographic system was controlled by LC solution version 1.25 , which was used for the data collection as well as data processing.

\section{Chromatographic conditions}

The chromatographic conditions for analysis utilized during the experimental work are given in Table 1.

\section{Preparation of $20 \mathrm{mM}$ phosphate buffer of pH $\mathbf{2 . 5}$}

PDP (2.72 g) was weighed and transferred into $1,000 \mathrm{ml}$ water, sonicated for 10 minutes, and dissolved. $\mathrm{pH} 2.5$ was adjusted with $5 \%$ orthophosphoric acid solution and filtered by using 0.45 $\mu \mathrm{m}$ nylon membrane filter (Cat no.: HNNX0902XXXX104, Make: Advanced Microdevices Pvt. Ltd.) under vacuum filtration.

\section{Preparation of the mobile phase}

$290 \mathrm{ml}$ of methanol and $290 \mathrm{ml}$ of acetonitrile were mixed with $420 \mathrm{ml}$ of $20 \mathrm{mM}$ phosphate buffer having a $\mathrm{pH} 2.5$ and degassed by 10 minutes of sonication.

\section{Preparation of the standard solution}

BSL (10 mg) and AMD (13.9 mg; equivalent to $10 \mathrm{mg}$ of amlodipine) standards were weighted and transferred into a $100 \mathrm{ml}$ dry volumetric flask. $70 \mathrm{ml}$ of the diluent was added and sonicated with intermediate shaking for 10 minutes to dissolve. After that, it was allowed to reach room temperature and with a diluent it was filled up to the mark and mixed well (concentration of BSL $=100 \mu \mathrm{g} / \mathrm{ml}$; concentration of amlodipine $=100 \mu \mathrm{g} / \mathrm{ml}$ ).

To confirm the suitability of standard, it was prepared in duplicate.

\section{Preparation of the sample solution}

The average weight of BSL and amlodipine tablets 5/5 mg $\left(\right.$ CORBIS $\left.^{\circledR} \mathrm{AM}-5\right)$ was determined from the weight of 20 tablets, and these tablets were powdered with the help of mortar and pestle. Subsequently, $373.6 \mathrm{mg}$ (equivalent to $10 \mathrm{mg} \mathrm{BSL}$ and $10 \mathrm{mg}$ amlodipine) of this fine powder was transferred into a $100 \mathrm{ml}$ dry volumetric flask. $70 \mathrm{ml}$ of the diluent was added and sonicated for 25 minutes with intermediate shaking. After sonication, it was allowed to reach room temperature and with a diluent it was filled up to the mark and mixed well. Finally, the resulting sample solution was filtered using Whatman filter paper (Cat No.: 1001-125, Make: GE Healthcare UK Ltd.) by discarding initial $5 \mathrm{ml}$ of the filtrate and used as assay sample solution. 

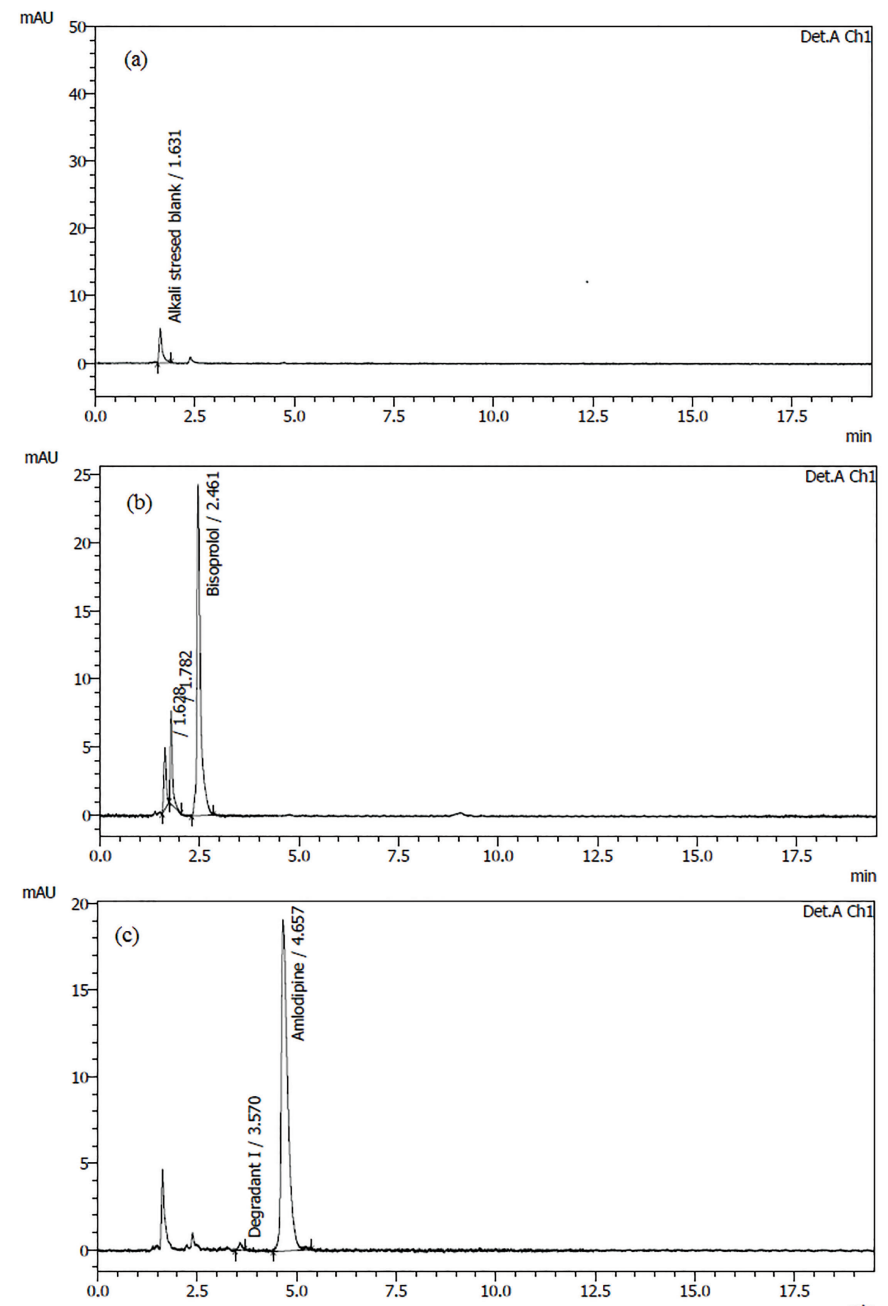

mAU

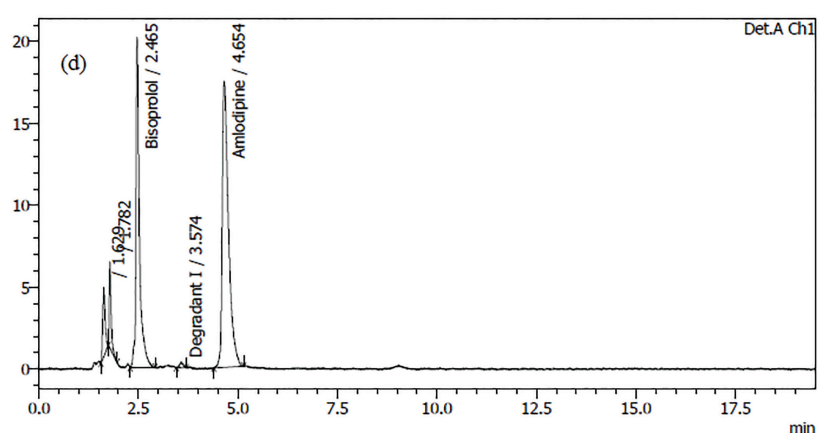

Figure 4. Chromatogram of alkali-stressed (a) blank, (b) BSL, (c) AMD, and (d) sample.

\section{METHOD VALIDATION}

The proposed RP-HPLC method was validated as per the ICH guideline Q2 (R1) (ICH, 2005).

\section{Specificity}

For specificity, blank solution interference at the retention time of BSL and AMD peaks was checked. Also, specificity was studied in forced degradation studies with a twofold increase in the actual run time of isocratic mode of elution to ensure that no late eluting degradation peaks. In this study, forced degradation was carried out by subjecting each drug substance individually and drug product sample $\left(\right.$ CORBIS $\left.{ }^{\circledR} \mathrm{AM}-5\right)$ with known concentration to various stress conditions like acid $(5 \mathrm{~N} \mathrm{HCl}, 3$ hours at room temperature), alkali ( $5 \mathrm{~N} \mathrm{NaOH}, 3$ hours at room temperature), oxidative $\left(6 \% \mathrm{v} / \mathrm{v}, \mathrm{H}_{2} \mathrm{O}_{2}, 3\right.$ hours at room temperature), thermal (dry heat at $60^{\circ} \mathrm{C}$ for 48 hours in hot air oven), photolytic (UV light for 24 hours in photostability chamber), and humidity (75\% relative humidity for 48 hours in stability chamber) degradations. Similarly, blank solutions (without active components) were prepared for acid, alkali, and oxidative stress conditions to check any interference at retention time of active analyte peaks. However, stress degradation samples were analyzed by using the proposed RP-HPLC method and results for mass balance ( $\%$ assay $+\%$ degradation) were determined for all the stressed samples against the standard and compared with the unstressed sample.

\section{System suitability and system repeatability}

The system suitability parameters such as retention time, tailing factor, theoretical plate count, and resolution were reported from the first injection of standard solution. The systems repeatability parameters are determined by injecting first standard solution (5 replicates) and second standard solution (1 replicate) in the chromatographic system and afterward determining the $\%$ relative standard deviation (\% RSD) for first standard and \% relative difference for second standard.

\section{Linearity}

Linearity was established at five different concentration levels prepared from standard stock solution (concentration of BSL $=500.69 \mu \mathrm{g} / \mathrm{ml}$ and amlodipine $=497.76 \mu \mathrm{g} / \mathrm{ml})$. It was carried out from $60 \%$ to $140 \%$ of the nominal working concentration in the range of $60.08-140.19 \mu \mathrm{g} / \mathrm{ml}$ and $59.73-139.37 \mu \mathrm{g} / \mathrm{ml}$ for BSL and AMD, respectively. The linearity graph for concentration versus peak area response was plotted and determined the squared correlation coefficient $\left(R^{2}\right)$.

\section{Detection limit (DL) and quantitation limit (QL)}

The DL and QL of BSL and AMD were determined based on the standard deviation of response (residual value) and the slope method. As per the ICH guidelines, the BSL and AMD calibration curves were determined by using the following formulae:

$$
\mathrm{DL}=\frac{3.3 \times \sigma}{S} \text { and } \quad \mathrm{QL}=\frac{10 \times \sigma}{S}
$$

where $\sigma=$ the standard deviation of the response and $S=$ the slope of the calibration curve.

\section{Accuracy}

Accuracy were assessed by analyses in triplicate sample containing placebo mixture with BSL and AMD at three concentrations: $60 \%, 100 \%$, and $140 \%$ of the nominal working concentration. At each level, samples were prepared in triplicate and every sample was injected once, and the mean recovery for triplicate samples at every concentration level was determined.

\section{Precision}

For the assay determination of BSL and AMD, the precision study was executed by using homogeneous sample. 


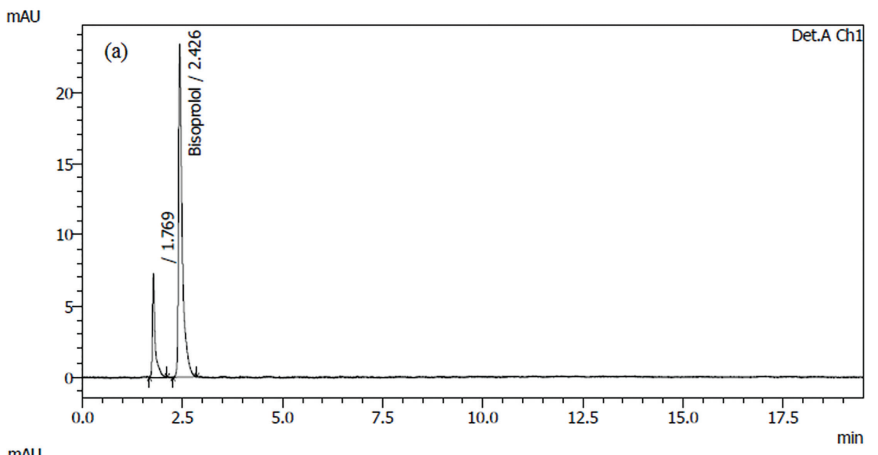

mAU

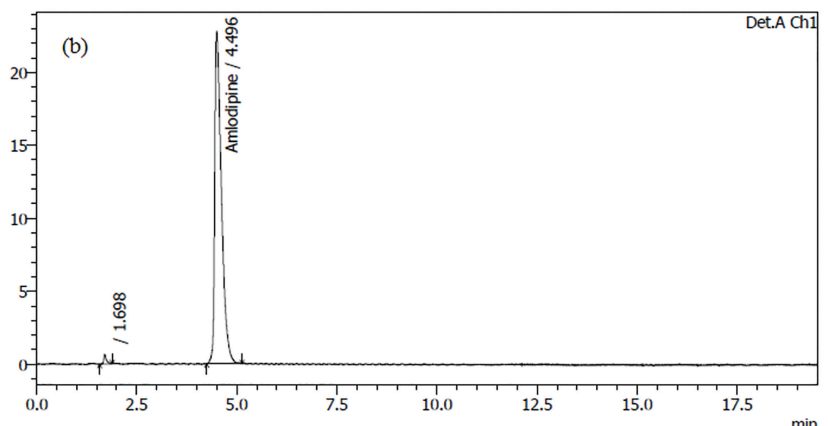

mAU

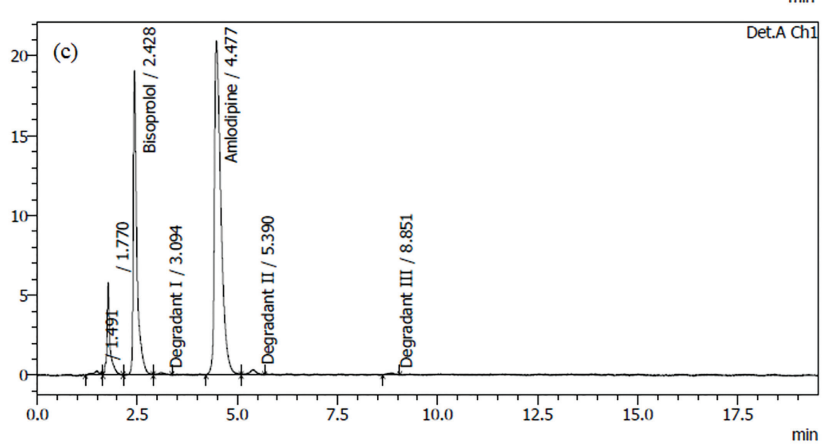

Figure 5. Chromatogram of thermal-stressed (a) BSL, (b) AMD, and (c) sample.

\section{Method repeatability}

Method repeatability of BSL and amlodipine tablets $5 / 5 \mathrm{mg}$ $\left(\right.$ CORBIS $^{\circledR}$ AM - 5) using batch no. 2013406TT (Marketed by: Torrent Pharmaceuticals Ltd., Mehsana, India) was established by injecting six sample preparations for assay as per proposed method. The $\%$ assay, $\%$ RSD, and $95 \%$ confidence interval $(95 \%$ CI) were calculated. Also, the system suitability and the system repeatability results were determined.

\section{Intermediate precision}

Intermediate precision was demonstrated from six determinations of the same sample of BSL and amlodipine tablets $5 / 5 \mathrm{mg}$ (i.e., batch, storage conditions, container, etc.) tested for method repeatability by different analysts on different days. Six replicate samples for the assay were prepared and the $\%$ assay, $\%$ $\mathrm{RSD}$, and $95 \%$ confidence interval $(95 \% \mathrm{CI})$ were calculated. The average results obtained in method repeatability were compared with the intermediate precision study. Also, the system suitability and the system repeatability results were determined.

\section{Robustness}

The method robustness was established by carrying out the deliberate alteration in method parameters. Filter compatibility was established for BSL and amlodipine tablets $5 / 5 \mathrm{mg}$ (CORBIS ${ }^{\circledR} \mathrm{AM}-$ 5) using three sample preparations and each sample was divided into three parts. First part was filtered by using Whatman filter (Cat no. 1001-125, Make: GE Healthcare UK Ltd.) by discarding the initial $5 \mathrm{ml}$ of the filtrate (as per method). The second part was filtered by using $0.45 \mu \mathrm{m}$ Polyvinylidene Fluoride (PVDF) syringe filter (Cat no. SYVF0602MNXX104, Make: Advanced Microdevices Pvt. Ltd.) by discarding the initial $5 \mathrm{ml}$ of the filtrate, and third part was filtered by using $0.45 \mu \mathrm{m}$ nylon syringe filter (Cat no. SYNN0602MNXX104, Make: Advanced Microdevices Pvt. Ltd.) by discarding the initial 5 $\mathrm{ml}$ of the filtrate and used as the sample solution. The $\%$ assay and $\%$ relative difference were calculated.

The extraction efficiency of method was demonstrated by carrying out alteration into sonication time during sample preparation from 20 to 30 minutes. Alteration in sonication time for preparation of sample was tested with three replicate preparations of sample of BSL and amlodipine tablets $5 / 5 \mathrm{mg}\left(\mathrm{CORBIS}^{\circledR} \mathrm{AM}-5\right)$ for each altered condition for calculating the $\%$ assay and $\%$ relative difference.

As part of the robustness study, deliberate change in chromatographic parameters with respect to changes in flow rate $( \pm 0.1)$ from 0.9 to $1.1 \mathrm{ml} /$ minute, change in the buffer composition of mobile phase $( \pm 10 \%)$ from 378:290:290 v/v to 462:290:290 $\mathrm{v} / \mathrm{v}$, change in $\mathrm{pH}( \pm 0.2)$ of mobile phase buffer from $\mathrm{pH} 2.3$ to 2.7 , change in the quantity of PDP for mobile phase buffer $( \pm 10 \%)$ from $2.448 \mathrm{~g} / 1,000 \mathrm{ml}$ to $2.992 \mathrm{~g} / 1,000 \mathrm{ml}$, and every changed condition impact on the method was evaluated. The results of system suitability and system repeatability parameters were checked for each changed conditions.

\section{Solution stability}

The standard solution stability was evaluated on duplicate preparations stored at room temperature and in the refrigerator $\left(2^{\circ} \mathrm{C}-8^{\circ} \mathrm{C}\right)$, and assessed after day 1 and day 2 . The results of the stored standard solution with freshly prepared standard solution were compared and the \% relative difference was calculated.

The sample solution stability was evaluated on three sample preparations (as per method) stored at room temperature and in the refrigerator $\left(2^{\circ} \mathrm{C}-8^{\circ} \mathrm{C}\right)$, and assessed after day 1 and day 2 . The results of the stored sample solution with initial sample solutions were compared and the \% relative difference between the percent assays was calculated.

Mobile phase preparation stability was assessed at bench top (room temperature) after day 1 and day 2. During evaluation of the mobile phase's stability, the results for change in appearance, system suitability, and system repeatability were checked.

\section{Range}

Linearity as well as accuracy for BSL and AMD was checked from $60 \%$ to $140 \%$ of the nominal working concentration. The method range was checked based on suitable linearity, accuracy, and precision results.

\section{RESULT AND DISCUSSION}

\section{Method development and chromatographic conditions optimization}

The consideration of specificity, accuracy, precision, linearity, robustness, and solution stability parameters for 


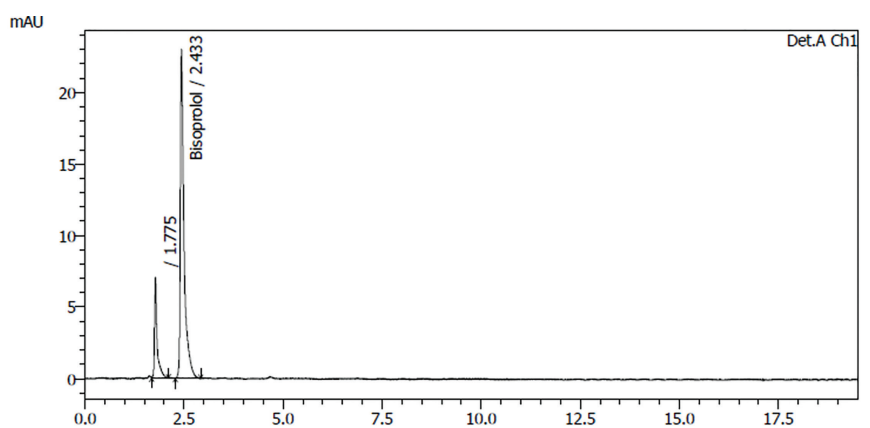

mAU

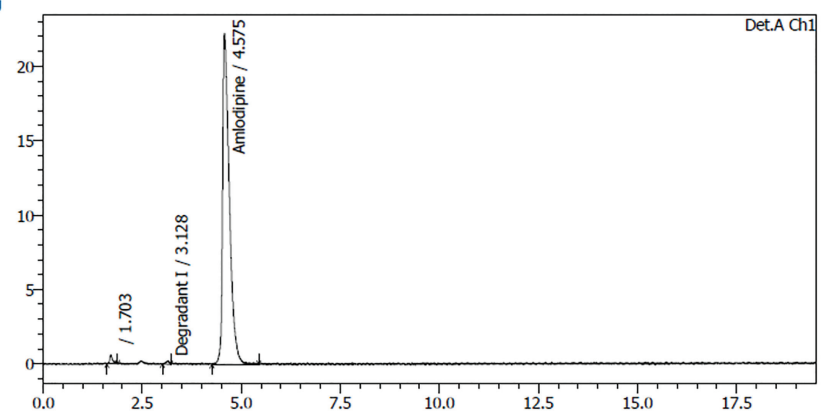

mAU

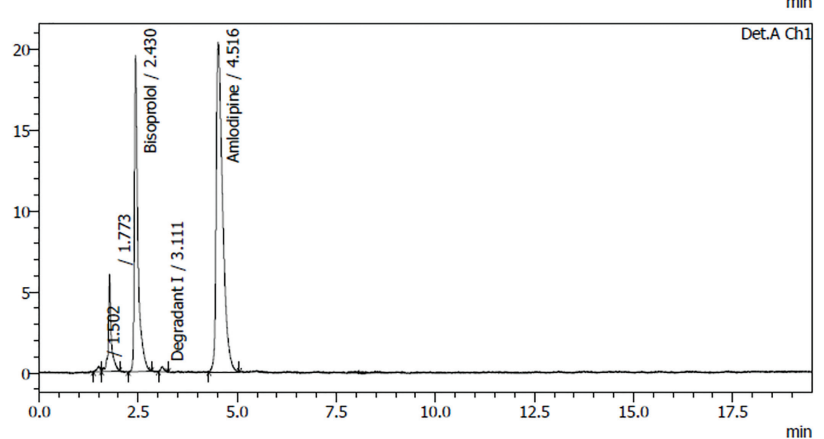

Figure 6. Chromatogram of photolytic (a) BSL, (b) AMD, and (c) sample.

development and validation of stability indicating method for BSL and AMD in bulk and in tablet dosage form. After optimization of a number of changed compositions, mobile phase was selected and afterward detection wavelength and flow rate were optimized. Also, method optimization performed by using the columns like Oyster ODS3 $(150 \times 4.6 \mathrm{~mm}, 5 \mu \mathrm{m})$ column $(\mathrm{P} / \mathrm{N}$ : S670153, Make: Merck) and ODS Hypersil, $250 \times 4.0 \mathrm{~mm}, 5 \mu \mathrm{m}(\mathrm{P} / \mathrm{N}: 30105-254030$, Make: Thermo Scientific). The organic modifiers like methanol and acetonitrile were used along with $20 \mathrm{mM}$ phosphate buffer at various $\mathrm{pH}$ levels, such as $2.3,2.5$, and 2.8 , to obtain the best peak shape with optimal resolution.

Finally, the mobile phase comprised the ratio of 420:290:290 v/v/v of $20 \mathrm{mM}$ phosphate buffer $\mathrm{pH} 2.5 \pm 0.05$ (adjusted with $5 \%$ orthophosphoric acid):methanol:acetonitrile was selected for simultaneous estimation of BSL and AMD because it retained both the peak efficiently in short time with satisfactory plate count (number of theoretical plates), tailing factor (symmetry factor), and resolution. Assay was performed by $1.0 \mathrm{ml} /$ minute flow rate at ambient (about $25^{\circ} \mathrm{C}$ ) column temperature and recorded the response with UV detector at 230 $\mathrm{nm}$. All quantitative calculations for assay of BSL and AMD were made on the basis of peak area response.
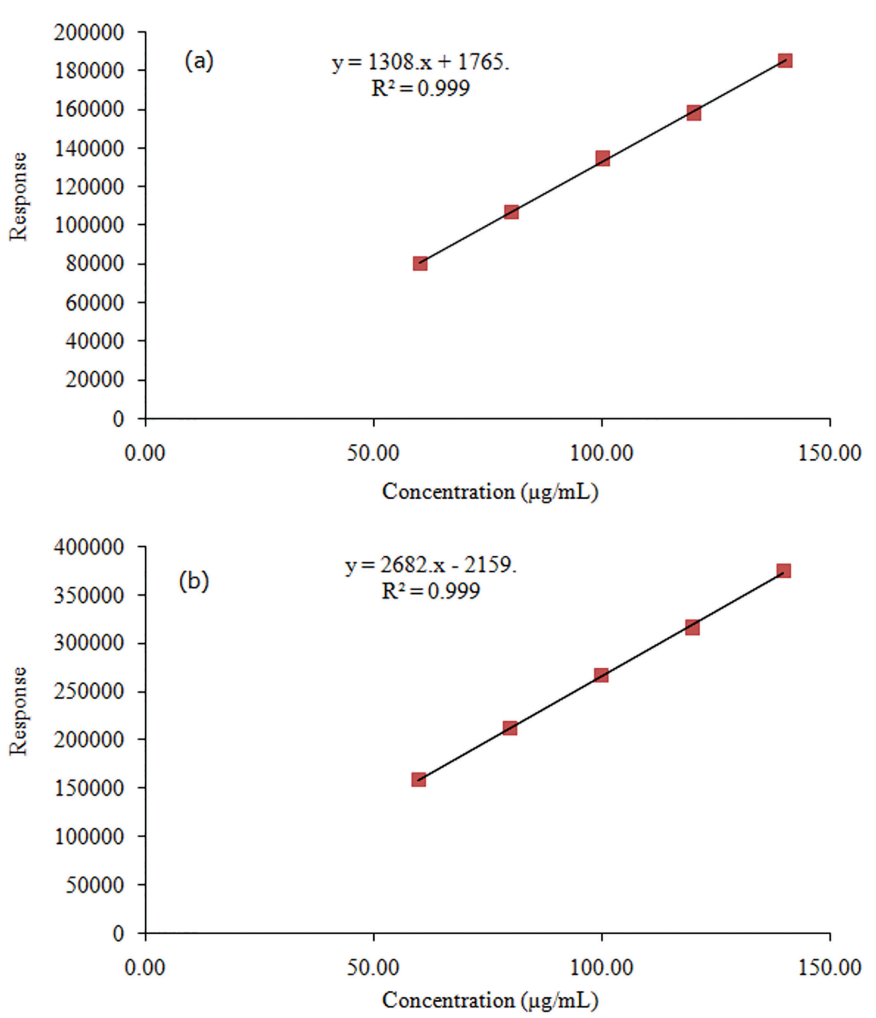

Figure 7. Linearity graph of (a) BSL and (b) amlodipine.

\section{METHOD VALIDATION}

\section{Specificity}

Specificity was established by demonstrating that there is no blank interference with BSL and AMD peaks (Fig. 2).

The forced degradation study was executed and interference was not observed from the degradation peaks at the retention time of BSL and AMD. The results of mass balance $(\%$ assay $+\%$ degradation) was determined for each stressed sample against standard and compared with unstressed sample. Mass balance data for BSL and AMD in their individual drug substance solution clearly showed that the response of BSL decreased in the acid-stressed sample, while the response of AMD decreased in acid- and alkali-stressed sample along with increase in the response of degradation peaks. In the acid-stressed sample, the major degradant observed at 2.263 minute and 3.221 for BSL and AMD respectively. The major degradant for AMD was observed at 3.570 minute in alkali-stressed and at 3.128 minute in photolyticstressed sample. Hence, the forced degradation studies showed that BSL drug substance was stable to alkali, oxidative, thermal, photolytic and humidity stressed condition while susceptible to acid-stressed condition; while AMD drug substance was stable to oxidative, thermal and humidity stressed condition while susceptible to acid, alkali and photolytic stress conditions.

Mass balance data for BSL and AMD in the sample solution clearly shows that the response of BSL decreased in the acidstressed samples while response of AMD decreased in acid, alkali, thermal and photolytic-stressed samples along with increase in 

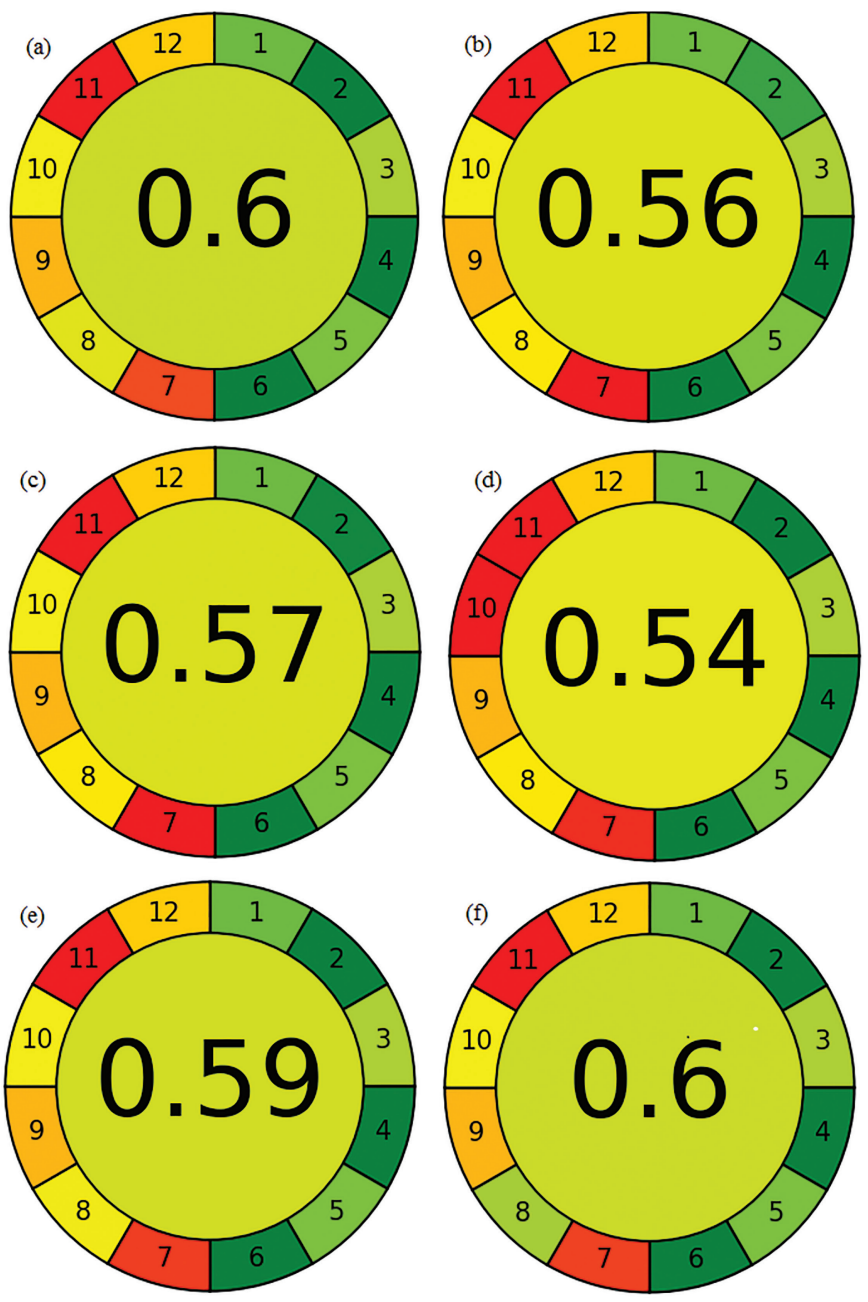

Figure 8. Results of greenness AGREE analysis for HPLC method. (a) Current method; (b) Patil et al.'s (2017) method; (c) Patil et al.'s (2014) method; (d) Pant and Pal's (2012) method; (e) Baokar et al.'s (2011) method; and (f) Vora and Kadav's (2008) method.

the response of degradation peaks. In the acid-stressed sample, the major degradant observed at 2.267 and 5.482 minute for BSL and AMD, respectively. In alkali-, thermal-, and photolyticstressed sample, the major degradant for AMD were observed at 3.574, 5.390, and 3.111 minutes, respectively. Hence, the forced degradation studies performed on drug product sample demonstrate that, BSL was stable to alkali-, oxidative-, thermal-, photolytic-, and humidity-stressed condition and susceptible to acid-stressed condition; AMD was stable to oxidative and humidity stressed condition and susceptible to acid, alkali, thermal and photolyticstressed condition.

A forced degradation study result shows that both drugs are stable at the oxidative and humidity stress condition. BSL is more stable in alkali and photolytic stress conditions and unstable in acid medium, while AMD is unstable in acid, alkali, thermal, and photolytic stress conditions. Hence, it is recommended that the BSL and AMD drug substances as well as the drug product should be stored in tightly closed containers and protected from light and heat. The forced degradation study results are summarized in Table 2 . The chromatograms of stressed samples (Fig. 3-6) show that the peaks due to degradation were well resolved from the drugs peak, demonstrating that the method is specific.

\section{System suitability and system repeatability}

The reproducibility aspects of any chromatographic system have been checked through system suitability and system repeatability parameters (Table 3 ).

\section{Linearity}

The method was found to be linear for BSL and AMD from $60 \%$ to $140 \%$ of the nominal working concentration in the range of $60.08-140.19 \mu \mathrm{g} / \mathrm{ml}$ and $59.73-139.37 \mu \mathrm{g} / \mathrm{ml}$ with squared correlation coefficient $\left(R^{2}\right)$ of 0.999 in both cases. Linearity results proved an excellent linear relationship for BSL and AMD in the studied concentration range, signifying the method suitability for analysis. Linearity study results are summarized in Table 4 and plots are shown in Figure 7.

\section{Detection limit and quantitation limit}

The DL was $2.29 \mu \mathrm{g} / \mathrm{ml}$ for BSL and $2.23 \mu \mathrm{g} / \mathrm{ml}$ for AMD, respectively, indicating that even small quantities of BSL and AMD can be detected.

The QL was $6.94 \mu \mathrm{g} / \mathrm{ml}$ for BSL and $6.74 \mu \mathrm{g} / \mathrm{ml} \mathrm{AMD,}$ respectively, indicating that even small quantities of BSL and AMD can be quantified.

\section{Accuracy}

The results of mean percent recovery obtained from triplicate samples at all level were found to be $99.26 \%, 99.81 \%$, and $98.97 \%$ for BSL and $98.70 \%, 99.61 \%$, and $99.26 \%$ for AMD at $60 \%, 100 \%$, and $140 \%$ of nominal working concentration, respectively, indicating that the method is accurate and shows that the excipients have no interference in the estimation (Table 5).

\section{Precision}

The results of method repeatability and intermediate precision showed that the \% RSD values were less than 2.0 for

Table 1. Chromatographic conditions.

\begin{tabular}{|c|c|c|}
\hline Parameters & & Description \\
\hline Type of system & : & HPLC with UV detector or equivalent \\
\hline Mobile phase (Eluent) & : & $\begin{array}{l}20 \mathrm{mM} \text { phosphate buffer } \mathrm{pH} \\
\text { 2.5:Methanol:Acetonitrile (420:290:290, } \\
\mathrm{v} / \mathrm{v} / \mathrm{v})\end{array}$ \\
\hline Column & : & $\begin{array}{l}\text { Oyster ODS3 }(150 \times 4.6 \mathrm{~mm}, 5 \mu \mathrm{m}) \text { column } \\
(\mathrm{P} / \mathrm{N}: \text { S670153, Make: Merck \& Co. })\end{array}$ \\
\hline Detection wavelength & : & $230 \mathrm{~nm}$ \\
\hline Flow rate & : & $1.0 \mathrm{ml} / \mathrm{minute}$ \\
\hline Volume of injection & : & $20 \mu 1$ \\
\hline Temperature of column & : & Ambient (about $25^{\circ} \mathrm{C}$ ) \\
\hline Pump mode & : & Isocratic \\
\hline Run time & : & 10 minutes \\
\hline Diluent/solvent & : & Mobile phase used as diluent \\
\hline
\end{tabular}


Table 2. Summarized results of forced degradation study.

\begin{tabular}{|c|c|c|c|c|c|c|c|c|c|c|c|c|c|}
\hline \multirow{3}{*}{$\begin{array}{c}\text { Name of the } \\
\text { sample }\end{array}$} & \multirow{3}{*}{ Condition } & \multicolumn{6}{|c|}{ Drug substance } & \multicolumn{6}{|c|}{ Drug product } \\
\hline & & \multicolumn{2}{|c|}{$\%$ assay } & \multicolumn{2}{|c|}{$\begin{array}{c}\% \text { total } \\
\text { degradation }\end{array}$} & \multicolumn{2}{|c|}{$\%$ mass balance } & \multicolumn{2}{|c|}{$\%$ assay } & \multicolumn{2}{|c|}{$\begin{array}{c}\% \text { total } \\
\text { degradation }\end{array}$} & \multicolumn{2}{|c|}{$\begin{array}{l}\% \text { mass } \\
\text { balance }\end{array}$} \\
\hline & & BSL & AMD & BSL & AMD & BSL & AMD & BSL & AMD & BSL & AMD & BSL & AMD \\
\hline Unstressed & As per test method & 99.88 & 98.99 & NTD & NTD & 99.88 & 98.99 & 98.76 & 99.66 & NTD & NTD & 98.76 & 99.66 \\
\hline Acid-stressed & $5 \mathrm{~N} \mathrm{HCl}$ for 3 hours at RT & 96.08 & 97.06 & 1.65 & 0.96 & 97.73 & 98.02 & 96.02 & 97.07 & 2.09 & 1.78 & 98.11 & 98.85 \\
\hline Alkali stressed & $5 \mathrm{~N} \mathrm{NaOH}$ for 3 hours at RT & 99.16 & 95.58 & NTD & 2.78 & 99.16 & 98.36 & 98.92 & 93.44 & NTD & 3.52 & 98.92 & 96.96 \\
\hline Oxidative stressed & $6 \% \mathrm{H}_{2} \mathrm{O}_{2}$ for 3 hours at RT & 99.44 & 99.53 & NTD & NTD & 99.44 & 99.53 & 100.25 & 98.79 & NTD & NTD & 100.25 & 98.79 \\
\hline Thermal stressed & $60^{\circ} \mathrm{C}$ for 48 hours in Oven & 99.50 & 100.16 & NTD & NTD & 99.50 & 100.16 & 97.86 & 91.15 & NTD & 5.83 & 97.86 & 98.53 \\
\hline Photolytic-stressed & UV light for 24 hours & 98.10 & 99.50 & NTD & 0.52 & 98.10 & 100.02 & 97.63 & 96.79 & NTD & 1.41 & 97.63 & 98.20 \\
\hline Humidity stressed & $75 \%$ RH for 48 hours & 100.10 & 99.47 & NTD & NTD & 100.10 & 99.47 & 99.40 & 98.00 & NTD & NTD & 99.40 & 98.00 \\
\hline
\end{tabular}

NTD $=$ Not detected RT $=$ Room temperature RH = Relative humidity .

Table 5. Summarized results for accuracy study.

Table 3. System suitability and system repeatability results.

\begin{tabular}{|c|c|c|c|}
\hline Parameters & BSL & AMD & $\begin{array}{l}\text { Acceptance } \\
\text { criteria }\end{array}$ \\
\hline Retention time (minutes) & 2.543 & 4.883 & - \\
\hline USP tailing factor (symmetry factor) & 1.45 & 1.23 & $0.8-2.0$ \\
\hline $\begin{array}{l}\text { USP plate counts (number of } \\
\text { theoretical plates) }\end{array}$ & 4,526 & 3,631 & $>2,000$ \\
\hline USP resolution & - & 9.79 & $>5.0$ \\
\hline $\begin{array}{l}\% \text { RSD of five replicate injections } \\
\text { of standard } 1\end{array}$ & 0.45 & 0.33 & $\leq 2.0 \%$ \\
\hline $\begin{array}{l}\text { The \% relative difference between } \\
\text { two standards }\end{array}$ & 1.31 & 1.14 & $\leq 2.0 \%$ \\
\hline
\end{tabular}

Table 4. Summarized linearity study results.

\begin{tabular}{|c|c|c|c|c|}
\hline \multirow{2}{*}{$\begin{array}{l}\text { Linearity } \\
\text { level }(\%)\end{array}$} & \multicolumn{2}{|c|}{ Concentration $(\mu \mathrm{g} / \mathrm{ml})$} & \multicolumn{2}{|c|}{ Peak area response } \\
\hline & BSL & AMD & BSL & AMD \\
\hline 60 & 60.08 & 59.85 & 79,924 & 158,760 \\
\hline 80 & 80.11 & 79.80 & 106,391 & 211,575 \\
\hline 100 & 100.14 & 99.75 & 134,291 & 266,669 \\
\hline 120 & 120.17 & 119.70 & 158,107 & 316,024 \\
\hline 140 & 140.19 & 139.65 & 185,063 & 374,126 \\
\hline \multicolumn{3}{|c|}{ Squared correlation coefficient $\left(\mathrm{r}^{2}\right) ; \geq 0.995$} & 0.999 & 0.999 \\
\hline \multicolumn{3}{|c|}{$\begin{array}{l}(Y \text {-intercept } / \text { response at } 100 \% \text { standard } \\
\text { concentration }) \times 100 ; \leq 3.0 \%\end{array}$} & 1.31 & 0.81 \\
\hline
\end{tabular}

\begin{tabular}{ccccccc}
\hline \multirow{2}{*}{$\begin{array}{c}\text { Accuracy } \\
\text { level }(\%)\end{array}$} & \multicolumn{2}{c}{$\begin{array}{c}\text { Concentration } \\
(\boldsymbol{\mu} / \mathrm{ml})\end{array}$} & \multicolumn{2}{c}{$\begin{array}{c}\text { Mean \% } \\
\text { recovery* }\end{array}$} & \multicolumn{2}{c}{$\%$ RSD } \\
\cline { 2 - 7 } & BSL & AMD & BSL & AMD & BSL & AMD \\
\hline 60 & 60 & 60 & 99.26 & 98.70 & 0.93 & 0.32 \\
100 & 100 & 100 & 99.81 & 99.61 & 0.27 & 0.34 \\
140 & 140 & 140 & 98.97 & 99.26 & 0.99 & 0.62 \\
\hline
\end{tabular}

*Mean of three replicates.

Table 6. Summarized \% assay results of precision study.

\begin{tabular}{ccccc}
\hline \multirow{2}{*}{ Sample no. } & \multicolumn{2}{c}{ Method repeatability } & \multicolumn{2}{c}{ Intermediate precision } \\
\cline { 2 - 5 } & BSL & AMD & BSL & AMD \\
\hline 1 & 99.53 & 100.08 & 100.30 & 100.10 \\
2 & 98.94 & 98.52 & 100.11 & 99.10 \\
3 & 98.58 & 98.54 & 100.19 & 100.09 \\
4 & 101.81 & 100.53 & 100.48 & 99.89 \\
5 & 98.24 & 101.43 & 100.56 & 99.20 \\
6 & 98.97 & 98.92 & 99.92 & 98.74 \\
Average & 99.35 & 99.67 & 100.26 & 99.52 \\
\% RSD & 1.29 & 1.20 & 0.24 & 0.58 \\
\% Relative & NA & NA & 0.91 & 0.15 \\
difference & & & $100.05-$ & $99.01-$ \\
95\% CI & $98.23-$ & $98.63-$ & 100.47 & 100.03 \\
\hline
\end{tabular}

NA $=$ Not applicable 
Table 7. Robustness results for filter compatibility.

\begin{tabular}{cccccc}
\hline \multirow{2}{*}{ Filter } & Sample no. & \multicolumn{2}{c}{ BSL } & \multicolumn{2}{c}{ AMD } \\
\cline { 3 - 6 } & & \% assay & $\begin{array}{c}\text { \% relative } \\
\text { Difference }\end{array}$ & $\begin{array}{c}\text { \% assay } \\
\text { \% relative } \\
\text { Difference }\end{array}$ \\
\hline $\begin{array}{c}\text { Whatman filter } \\
\text { (As per method) }\end{array}$ & 1 & 101.81 & NA & 100.53 & NA \\
& 2 & 98.24 & NA & 101.43 & NA \\
$0.45 \mu$ m Nylon & 3 & 98.97 & NA & 98.92 & NA \\
syringe filter & 1 & 99.76 & 2.04 & 98.91 & 1.63 \\
& 2 & 99.25 & 1.02 & 99.69 & 1.73 \\
$0.45 \mu$ m PVDF & 3 & 98.32 & 0.66 & 97.89 & 1.05 \\
syringe filter & 1 & 100.48 & 1.32 & 99.83 & 0.70 \\
& 2 & 99.48 & 1.25 & 100.45 & 0.97 \\
& 3 & 99.60 & 0.63 & 98.63 & 0.29 \\
\hline
\end{tabular}

$\mathrm{NA}=$ Not applicable

Table 8. Results of robustness for change in sonication time.

\begin{tabular}{|c|c|c|c|c|c|c|c|}
\hline \multirow{2}{*}{$\begin{array}{c}\text { Sample } \\
\text { sonication } \\
\text { (minutes) }\end{array}$} & \multirow{2}{*}{$\begin{array}{c}\text { Sample } \\
\text { no. }\end{array}$} & \multicolumn{3}{|c|}{ BSL } & \multicolumn{3}{|c|}{ AMD } \\
\hline & & $\%$ assay & Average & $\%$ RD & $\%$ assay & Average & $\begin{array}{c}\% \\
\text { RD }\end{array}$ \\
\hline 25 & 1 & 99.53 & 99.02 & NA & 100.08 & 99.05 & NA \\
\hline \multirow{2}{*}{$\begin{array}{l}\text { (as per } \\
\text { method) }\end{array}$} & 2 & 98.94 & & & 98.52 & & \\
\hline & 3 & 98.58 & & & 98.54 & & \\
\hline \multirow[t]{3}{*}{20} & 1 & 98.92 & 99.58 & 0.57 & 99.30 & 99.27 & 0.22 \\
\hline & 2 & 100.36 & & & 99.61 & & \\
\hline & 3 & 99.47 & & & 98.89 & & \\
\hline \multirow[t]{3}{*}{30} & 1 & 100.09 & 99.28 & 0.26 & 99.74 & 100.25 & 1.21 \\
\hline & 2 & 98.33 & & & 102.22 & & \\
\hline & 3 & 99.42 & & & 98.80 & & \\
\hline
\end{tabular}

$\mathrm{NA}=$ Not applicable; $\% \mathrm{RD}=\%$ r elative difference.

Table 9. Robustness results for change in chromatographic parameters.

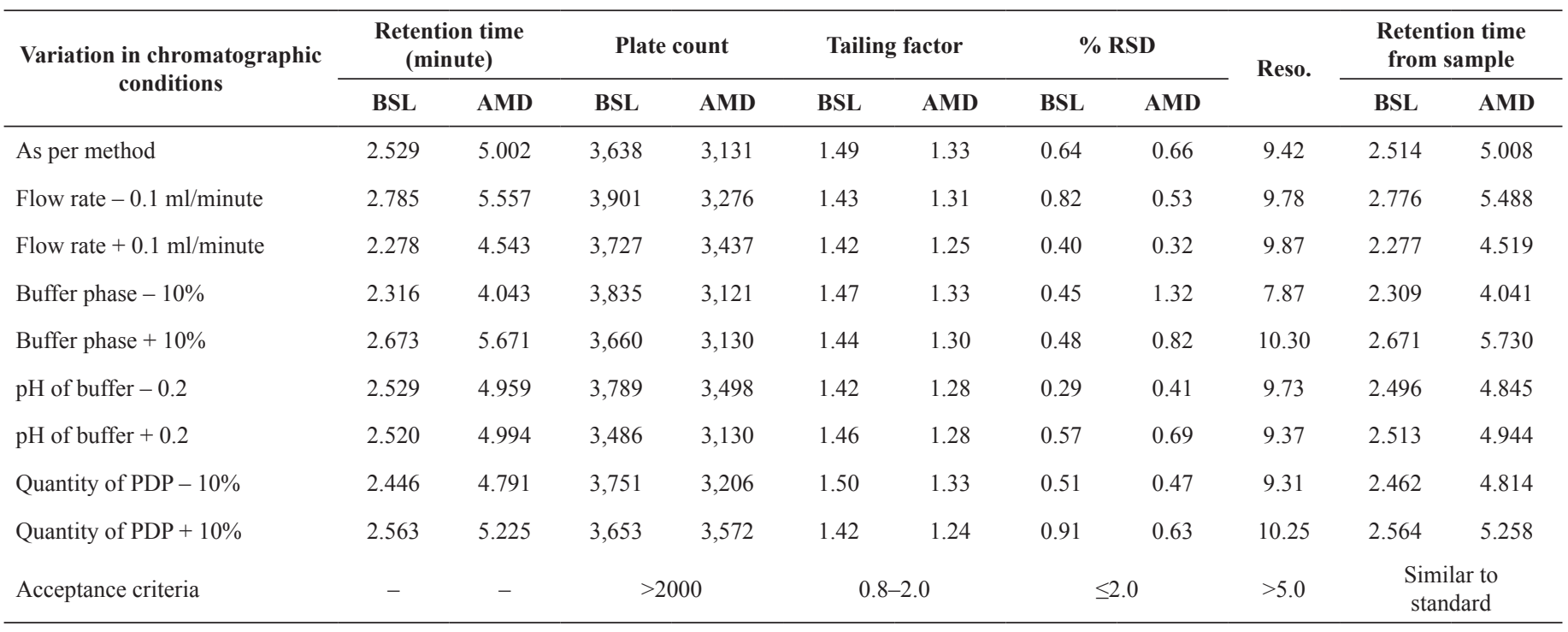

Reso. $=$ USP resolution between BSL and AMD peak. 
Table 10. Standard solution stability (room temperature).

\begin{tabular}{|c|c|c|c|c|c|c|}
\hline \multirow{3}{*}{$\begin{array}{c}\text { Time in } \\
\text { days }\end{array}$} & \multicolumn{3}{|c|}{ First standard solution } & \multicolumn{3}{|c|}{ Second standard solution } \\
\hline & \multicolumn{2}{|c|}{ Response/mg } & \multirow{2}{*}{$\begin{array}{l}\% \text { relative } \\
\text { difference }\end{array}$} & \multicolumn{2}{|c|}{ Response/mg } & \multirow{2}{*}{$\begin{array}{l}\% \text { relative } \\
\text { difference }\end{array}$} \\
\hline & $\begin{array}{c}\text { Fresh } \\
\text { standard }\end{array}$ & $\begin{array}{c}\text { Stored } \\
\text { standard }\end{array}$ & & $\begin{array}{c}\text { Fresh } \\
\text { standard }\end{array}$ & $\begin{array}{c}\text { Stored } \\
\text { standard }\end{array}$ & \\
\hline & \multicolumn{6}{|c|}{ BSL } \\
\hline Initial & $12,597.53$ & NA & NA & $12,764.90$ & NA & NA \\
\hline 1 & $12,546.92$ & $12,456.24$ & 0.73 & $12,546.92$ & $12,747.00$ & 1.57 \\
\hline \multirow[t]{2}{*}{2} & $12,554.83$ & $12,403.07$ & 1.22 & $12,554.83$ & $12,678.40$ & 0.97 \\
\hline & \multicolumn{6}{|c|}{ AMD } \\
\hline Initial & $18,268.87$ & NA & NA & $18,479.36$ & NA & NA \\
\hline 1 & $17,883.39$ & $17,643.31$ & 1.36 & $17,883.39$ & $17,918.07$ & 0.19 \\
\hline 2 & $17,958.04$ & $18,136.77$ & 0.99 & $17,958.04$ & $17,809.43$ & 0.83 \\
\hline
\end{tabular}

Table 11. Standard solution stability (refrigerator, $2^{\circ} \mathrm{C}-8^{\circ} \mathrm{C}$ ).

\begin{tabular}{|c|c|c|c|c|c|c|}
\hline \multirow{3}{*}{$\begin{array}{l}\text { Time in } \\
\text { days }\end{array}$} & \multicolumn{3}{|c|}{ First standard solution } & \multicolumn{3}{|c|}{ Second standard solution } \\
\hline & \multicolumn{2}{|c|}{ Response/mg } & \multirow{2}{*}{$\begin{array}{l}\% \text { relative } \\
\text { difference }\end{array}$} & \multicolumn{2}{|c|}{ Response/mg } & \multirow{2}{*}{$\begin{array}{l}\text { \% relative } \\
\text { difference }\end{array}$} \\
\hline & Fresh standard & Stored standard & & Fresh standard & Stored standard & \\
\hline & \multicolumn{6}{|c|}{ BSL } \\
\hline Initial & $12,597.53$ & NA & NA & $12,764.90$ & NA & NA \\
\hline 1 & $12,546.92$ & $12,666.53$ & 0.94 & $12,546.92$ & $12,617.70$ & 0.56 \\
\hline \multirow[t]{2}{*}{2} & $12,554.83$ & $12,536.73$ & 0.14 & $12,554.83$ & $12,592.30$ & 0.30 \\
\hline & \multicolumn{6}{|c|}{ AMD } \\
\hline Initial & $18,268.87$ & NA & NA & $18,479.36$ & NA & NA \\
\hline 1 & $17,883.39$ & $17,788.94$ & 0.53 & $17,883.39$ & $18,105.21$ & 1.23 \\
\hline 2 & $17,958.04$ & $17,720.42$ & 1.34 & $17,958.04$ & $17,830.43$ & 0.72 \\
\hline
\end{tabular}

Table 12. Summary of the results of stability of sample solutions.

\begin{tabular}{|c|c|c|c|c|c|c|c|c|c|}
\hline \multirow{3}{*}{$\begin{array}{c}\text { Time in } \\
\text { day }\end{array}$} & \multirow{3}{*}{ Sample } & \multicolumn{4}{|c|}{ Room temperature } & \multicolumn{4}{|c|}{ Refrigerator $\left(2^{\circ} \mathrm{C}-8^{\circ} \mathrm{C}\right)$} \\
\hline & & \multicolumn{2}{|c|}{$\%$ assay } & \multicolumn{2}{|c|}{$\begin{array}{l}\% \text { relative } \\
\text { difference }\end{array}$} & \multicolumn{2}{|c|}{$\%$ assay } & \multicolumn{2}{|c|}{$\begin{array}{l}\% \text { relative } \\
\text { difference }\end{array}$} \\
\hline & & BSL & AMD & BSL & AMD & BSL & AMD & BSL & AMD \\
\hline \multirow[t]{3}{*}{ Initial } & 1 & 99.53 & 100.08 & NA & NA & 99.53 & 100.08 & NA & NA \\
\hline & 2 & 98.94 & 98.52 & NA & NA & 98.94 & 98.52 & NA & NA \\
\hline & 3 & 98.58 & 98.54 & NA & NA & 98.58 & 98.54 & NA & NA \\
\hline \multirow[t]{3}{*}{ Day 1} & 1 & 99.78 & 99.82 & 0.25 & 0.26 & 98.07 & 100.95 & 1.48 & 0.86 \\
\hline & 2 & 98.74 & 100.02 & 0.20 & 1.52 & 99.54 & 98.12 & 0.60 & 0.41 \\
\hline & 3 & 99.80 & 98.76 & 1.23 & 0.22 & 100.75 & 99.87 & 2.18 & 1.34 \\
\hline \multirow[t]{3}{*}{ Day 2} & 1 & 99.63 & 99.00 & 0.10 & 1.09 & 99.80 & 99.59 & 0.27 & 0.49 \\
\hline & 2 & 98.80 & 97.98 & 0.14 & 0.55 & 100.27 & 99.42 & 1.33 & 0.91 \\
\hline & 3 & 98.32 & 100.56 & 0.27 & 2.03 & 98.91 & 99.26 & 0.34 & 0.72 \\
\hline
\end{tabular}

$\mathrm{NA}=$ not applicable. 
Table 13. Mobile phase stability results.

\begin{tabular}{|c|c|c|c|c|c|c|c|c|c|c|c|}
\hline \multirow{2}{*}{$\begin{array}{l}\text { Time } \\
\text { in } \\
\text { days }\end{array}$} & \multicolumn{2}{|c|}{$\begin{array}{l}\text { Retention time } \\
\quad \text { (minute) }\end{array}$} & \multicolumn{2}{|c|}{$\begin{array}{l}\text { Plate } \\
\text { count }\end{array}$} & \multicolumn{2}{|c|}{$\begin{array}{l}\text { Tailing } \\
\text { factor }\end{array}$} & \multicolumn{2}{|c|}{$\%$ RSD } & \multirow{2}{*}{ Reso. } & \multicolumn{2}{|c|}{ RT from sample } \\
\hline & BSL & AMD & BSL & AMD & BSL & AMD & BSL & AMD & & BSL & AMD \\
\hline Initial & 2.543 & 4.883 & 4526 & 3,631 & 1.45 & 1.23 & 0.45 & 0.33 & 9.79 & 2.516 & 4.812 \\
\hline 1 & 2.524 & 4.961 & 4640 & 3,873 & 1.50 & 1.29 & 0.62 & 0.70 & 10.43 & 2.525 & 4.975 \\
\hline 2 & 2.539 & 4.979 & 4757 & 3,685 & 1.46 & 1.28 & 0.78 & 0.36 & 10.27 & 2.488 & 4.835 \\
\hline \multicolumn{3}{|c|}{ Acceptance criteria } & \multicolumn{2}{|c|}{$>2,000$} & \multicolumn{2}{|c|}{$0.8-2.0$} & \multicolumn{2}{|c|}{$\leq 2.0$} & $>5.0$ & \multicolumn{2}{|c|}{ Similar to standard } \\
\hline
\end{tabular}

Reso. $=$ Resolution between BSL and AMD peak; $\mathrm{RT}=$ Retention time in minutes.

Table 14. Comparison of the reported methods for simultaneous estimation of BSL and AMD.

\begin{tabular}{|c|c|c|c|c|c|c|}
\hline Parameters & $\begin{array}{l}\text { Vora and Kadav, } \\
2008\end{array}$ & Baokar et al., 2011 & Pant and Pal, 2012 & Patil et al., 2014 & Patil et al., 2017 & $\begin{array}{c}\text { Proposed } \\
\text { method }\end{array}$ \\
\hline Type of system & $\begin{array}{l}\text { HPLC with PDA } \\
\text { detector }\end{array}$ & $\begin{array}{l}\text { HPLC with UV } \\
\text { detector }\end{array}$ & $\begin{array}{l}\text { HPLC with PDA/ } \\
\text { UV detector }\end{array}$ & $\begin{array}{l}\text { HPLC with UV } \\
\text { detector }\end{array}$ & $\begin{array}{l}\text { HPLC with UV } \\
\text { detector }\end{array}$ & $\begin{array}{l}\text { HPLC with } \\
\text { UV detector }\end{array}$ \\
\hline $\begin{array}{l}\text { Mobile phase } \\
\text { (Eluent) }\end{array}$ & $\begin{array}{l}25 \mathrm{mM} \text { ammonium } \\
\text { acetate adjusted } \\
\text { to } \mathrm{pH} 5.0 \text { with acetic } \\
\text { acid and methanol } \\
(65: 35, \mathrm{v} / \mathrm{v})\end{array}$ & $\begin{array}{l}\text { Methanol:Acetonitrile: } \\
50 \mathrm{mM} \text { PDP buffer } \\
(25: 30: 45, \mathrm{v} / \mathrm{v}) \text { at } \\
\text { pH } 3.0\end{array}$ & $\begin{array}{l}\text { A mixture of } \\
\text { buffer prepared } \\
\text { by } 0.4 \mathrm{ml} \text { of TEA } \\
\text { and } 3.12 \mathrm{~g} \text { of } \\
\text { sodium dihydrogen } \\
\text { orthophosphate } \\
\text { in } 1,000 \mathrm{ml} \text { water } \\
\text { adjusted to } \mathrm{pH} 3.0 \pm \\
0.05 \text { and acetonitrile } \\
(50: 50, \mathrm{v} / \mathrm{v})\end{array}$ & $\begin{array}{l}\text { Methanol, } \\
\text { Acetonitrile, and } 50 \\
\text { Mm PDP buffer of } \\
\text { pH } 3.0 \text { ( } 25: 30: 45, \\
\text { v/v/v) }\end{array}$ & $\begin{array}{l}\text { Acetonitrile:Methanol: } \\
50 \mathrm{mM} \text { PDP } \\
(25: 25: 50, \mathrm{v} / \mathrm{v} / \mathrm{v})\end{array}$ & $\begin{array}{l}20 \mathrm{mM} \text { phosphate } \\
\text { buffer } \mathrm{pH} \\
\text { 2.5:Methanol: } \\
\text { Acetonitrile } \\
(420: 290: 290 \text {, } \\
\mathrm{v} / \mathrm{v} / \mathrm{v})\end{array}$ \\
\hline Column & $\begin{array}{l}\text { Luna C18-2 }(50 \times \\
4.6 \mathrm{~mm} \mathrm{ID}, 3 \mu)\end{array}$ & $\begin{array}{l}\text { C18 Intersil } 4.6 \times 150 \\
\text { mm (id)* }\end{array}$ & $\begin{array}{l}\text { Luna C18 }(250 \times 4.6 \\
\text { mm, } 5 \mu) \text {, as well as } \\
\text { Hibar }(\mathrm{R}) \mathrm{RP}-18 \mathrm{e} \\
(250 \times 4.6 \mathrm{~mm}, 5 \mu)\end{array}$ & $\begin{array}{l}\text { Kya Tech., Sil C-18 } \\
\text { HS }(250 \times 4.6 \mathrm{~mm} \text {, } \\
10 \mu \mathrm{m})\end{array}$ & $\begin{array}{l}\text { Agilent C18 }(250 \times \\
4.6 \mathrm{~mm}, 5 \mu \mathrm{m})\end{array}$ & $\begin{array}{l}\text { Oyster ODS3 } \\
(150 \times 4.6 \mathrm{~mm} \text {, } \\
5 \mu \mathrm{m}) \text { column } \\
(\mathrm{P} / \mathrm{N}: \mathrm{S} 670153 \text {, } \\
\text { Make: Merck \& } \\
\text { Co. })\end{array}$ \\
\hline $\begin{array}{l}\text { Detection } \\
\text { wavelength }\end{array}$ & $230 \mathrm{~nm}$ & $267 \mathrm{~nm}$ & $230 \mathrm{~nm}$ & $267 \mathrm{~nm}$ & $274 \mathrm{~nm}$ & $230 \mathrm{~nm}$ \\
\hline Flow rate & $0.8 \mathrm{ml} /$ minute & $1.0 \mathrm{ml} /$ minute & $1.0 \mathrm{ml} /$ minute & $1.0 \mathrm{ml} /$ minute & $1.0 \mathrm{ml} /$ minute & $1.0 \mathrm{ml} /$ minute \\
\hline $\begin{array}{l}\text { Temperature of } \\
\text { column }\end{array}$ & Not reported & Not reported & $25^{\circ} \mathrm{C}$ & Not reported & Not reported & $\begin{array}{l}\text { Ambient (about } \\
25^{\circ} \mathrm{C} \text { ) }\end{array}$ \\
\hline Pump mode & Isocratic & Isocratic & Isocratic & Isocratic & Isocratic & Isocratic \\
\hline Run time & 5 minutes & 12 minutes & 10 minutes & 10 minutes & 15 minutes & 10 minutes \\
\hline $\begin{array}{l}\text { Resolution between } \\
\text { BSL and AMD } \\
\text { peak }\end{array}$ & 14.2 & Not reported & 7.46 & 14.08 & 4.42 & 9.79 \\
\hline $\begin{array}{l}\text { Greenness } \\
\text { assessment using } \\
\text { AGREE value }\end{array}$ & 0.60 & 0.59 & 0.54 & 0.57 & 0.56 & 0.60 \\
\hline
\end{tabular}




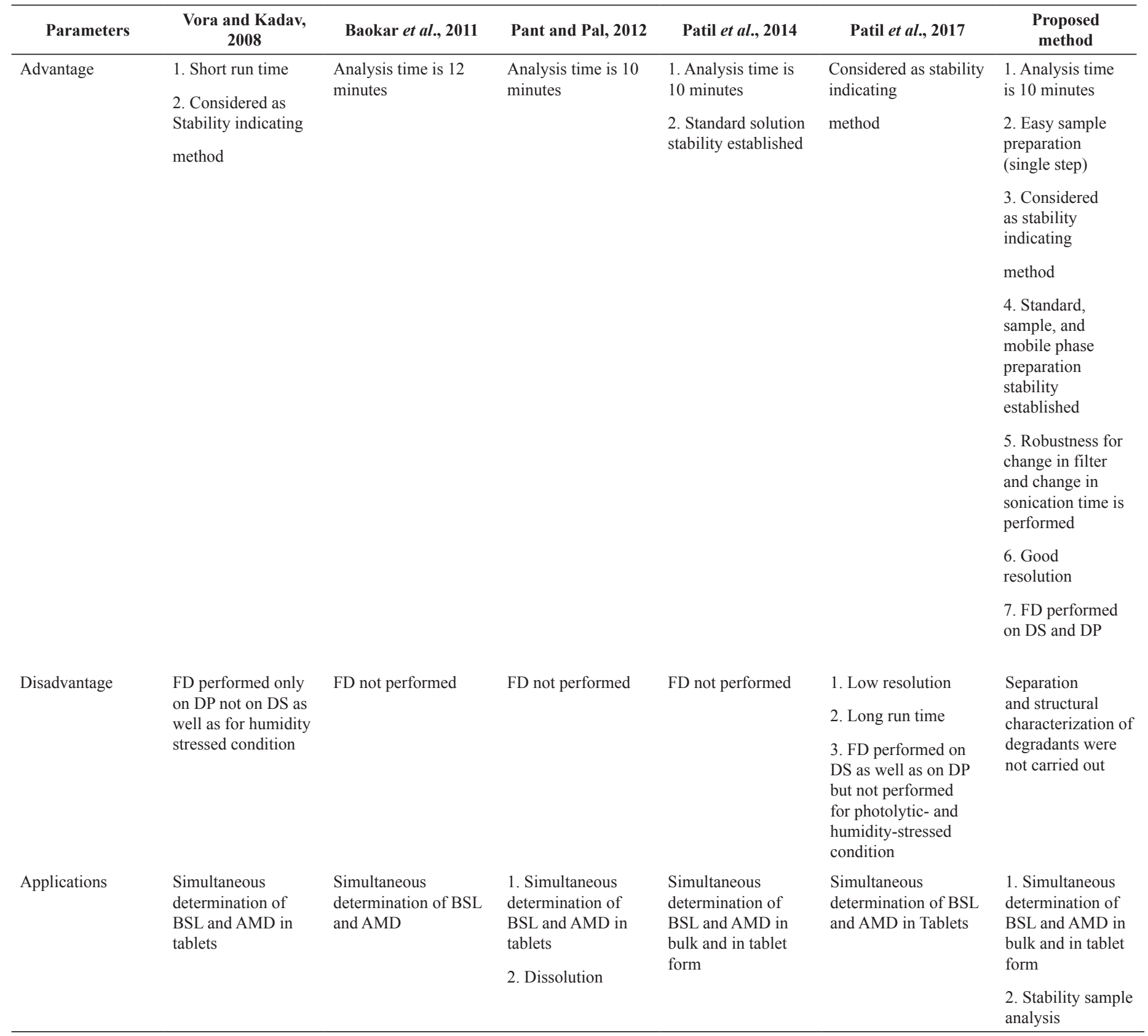

*Particle size not reported by Author; FD = Forced degradation; $\mathrm{DS}=$ Drug substance; $\mathrm{DP}=$ Drug product.

BSL and AMD, demonstrating that the method is reproducible and precise (Table 6).

\section{Robustness}

The results of the sample filtered through $0.45 \mu \mathrm{m}$ nylon syringe filter and $0.45 \mu \mathrm{m}$ PVDF syringe filter met the acceptance criteria for $\%$ relative difference (it should be $\leq 3.0 \%$ ) with results of sample filtered through Whatman filter paper (as per method). Thus, besides Whatman filter paper, $0.45 \mu \mathrm{m}$ PVDF syringe filter and $0.45 \mu \mathrm{m}$ nylon syringe filter were useful for assay samples (Table 7).

The results of extraction efficiency of BSL and AMD tablets $5 / 5 \mathrm{mg}\left(\mathrm{CORBIS}^{\circledR} \mathrm{AM}-5\right)$ were not influenced by altering the sample sonication time from 20 to 30 minutes, and as a result
(Table 8 ) they met acceptance criteria for $\%$ relative difference (it should be $\leq 3.0 \%$ ).

For each changed method parameter during robustness study, the results of system suitability, system repeatability, and change in retention time were checked. The acceptance criteria were met for each chromatographic method parameter even after making the deliberate changes into it, demonstrating its robustness (Table 9).

\section{Solution stability}

The results of standard solution stability at bench top (room temperature) and in the refrigerator $\left(2^{\circ} \mathrm{C}-8^{\circ} \mathrm{C}\right)$ met the acceptance criteria (\% relative difference between studied and initial time point is $\leq 2.0 \%$ ), revealing that the standard solutions were stable for 2 days (Tables 10 and 11). 
The sample solutions at bench top (room temperature) and in the refrigerator $\left(2^{\circ} \mathrm{C}-8^{\circ} \mathrm{C}\right)$ were stable for 2 days as the $\%$ relative difference between the percent assay results (Table 12) obtained from initial sample solutions and stored sample solutions met the acceptance criteria (the $\%$ relative difference among initial and stored time point is $\leq 3.0 \%$ ).

During estimation of mobile phase stability, the appearance of mobile phase was found to be clear and free of visible particles. Also, the system suitability and system repeatability results (Table 13) met the acceptance criteria, indicating that the mobile phase at bench top (room temperature) was stable for 2 days.

Based on solution stability data, it is recommended that standard solution, sample solution, and mobile phase can be used up to 2 days from their time of preparation.

\section{Range}

The method range is from $60 \%$ to $140 \%$ of the nominal working standard solution has been derived for BSL and AMD based on acceptable linearity, accuracy, and precision study results.

\section{Comparison of the reported methods for simultaneous estimation of BSL and AMD}

In comparison with the earlier reported work as well as conducting in-depth study in the current research, it was found that the current research offers various advantages like improved resolution, short run time, less time-consuming process, and also more eco-friendly (Table 14).

The results for system suitability and system repeatability parameters were established with preparations of two standard solutions. Moreover, robustness study provides additional benefits for filter compatibility study and change in sonication time. The solution stability was reported for preparations of mobile phase as well as for standard and sample solutions. The forced degradation study was also performed on drug substances individually and their combination drug product with a suitable experimental design. In addition to this, it is more economic as simple solution preparations require less time of analysis. The experimental results obtained during the validation recommend that this method is more simple, rapid, specific, precise, accurate, linear, and robust enough as compared to the reported methods.

A number of new tools for assessing the greenness of analytical procedures have recently been introduced, which includes National Environmental Methods Index, Eco-Scale Assessment, Green Analytical Procedure Index, and AGREE: Analytical GREEnness metric, and each metric system is characterized by their advantages and disadvantages (Gamal et. al., 2021). Green analytical chemistry aims to make analytical techniques less harmful to the environment and safer to human. The AGREE tool useful to convert each of the 12 green analytical chemistry criteria into scores with the goal of comprehensively evaluating the greenness of analytical methodologies (PenaPereira et. al., 2020). The current method of greenness was determined by using the software tool AGREE: Analytical
GREeenEss Calculator version 0.5 and was compared with the old HPLC methods (Fig. 8).

However, in the current work, the separation and structural characterization of degradants were not carried out. The current research can be extended further to separate out the degradants and structural characterization of the same to identify the correct chemical structures of drug degradation products which will help in providing better quality control and quality assurance attributes for pharmaceutical industries.

\section{CONCLUSION}

The RP-HPLC method with a stability-indicating feature for simultaneous determination of BSL and AMD in bulk and in tablet dosage form was developed and validated as per the guidelines of ICH. The study results show that the chromatographic method is linear in the measured concentration range as well as specific, accurate, precise, and robust. Experimental results of forced degradation study reveals that all the degradation peaks were well separated from the active component(s) peak, signifying the method is specific and stability-indicating. The percent recovery results for dosage forms indicated that there was no interference from the excipients in the active components determination. The values for \% RSD were less than 2.0 for method repeatability and intermediate precision signifying the high level of method precision. The values for detection limits and quantitation limits provide additional benefits as it is found to be very low. The results of deliberate changes made in method parameters signify robustness of method. The results of solution stability reveal that the solutions of standard, sample, and mobile phase are stable for 2 days. In addition to this, drugs analysis is rapid and cost-effective as the method has easy extraction and sample preparation process with simple isocratic elution. The developed method can be useful for regular analysis as well as stability studies of BSL and AMD in the quality control of finished product and also in bulk manufacturing.

\section{CONFLICT OF INTEREST}

The authors declare no conflicts of interest.

\section{FUNDING}

None.

\section{AUTHOR CONTRIBUTIONS}

Each author contributed to the conception, design, and execution of this study and also agreed to submit to the current journal.

\section{ACKNOWLEDGMENT}

The authors would like to thanks RUSA Centre for Herbo Medicinal Studies and School of Pharmacy, Swami Ramanand Teerth Marathwada University, Nanded - 431606, Maharashtra India for providing instrumental, laboratory, chemical and other required facilities during research work. Also, authors are thankful to Unichem Laboratories Ltd., Goa - India for supplying gift samples of Bisoprolol Fumarate and Amlodipine Besylate. 


\section{REFERENCES}

Alsante KM, Baertschi SW, Coutant M, Marquez BL, Sharp TR, Zelesky TC. Degradation and impurity analysis for pharmaceutical drug candidates. In: Ahuja S, Scypinski S (eds.). Handbook of modern pharmaceutical analysis, Elsevier Science Publishing Co Inc., San Diego, CA, pp 59-169,

Aubry AF, Tattersall P, Ruan J. Development of stability indicating methods. In: Huynh-Ba K (ed.). Handbook of stability testing in pharmaceutical development, Springer, New York, NY, pp 139-61,

Baokar SB, Erande RS, Shaikh SG. Analytical method development and validation for simultaneous determination of bisoprolol fumarate and amlodipine besylate. Indo Am J Pharm Res, 2011; 2(1):100-10.

Blessy M, Patel RD, Prajapati PN, Agrawal YK. Development of forced degradation and stability indicating studies of drugs-a review. J Pharm Anal, 2014; 4(3):159-65.

Da Silva Medeiros T, Pinto EC, Cabral LM, De Sousa VP. Tobramycin: a review of detectors used in analytical approaches for drug substance, its impurities and in pharmaceutical formulation. Microchem J, $2020 ; 160$ (B): 105658 .

European Pharmacopoeia 10.0. European directorate for the quality of medicines and healthcare. 2020.

Gamal M, Naguib IA, Panda DS, Abdallah FF. Comparative study of four greenness assessment tools for selection of greenest analytical method for assay of hyoscine $N$-butyl bromide. Anal Methods, 2021; 13(3):369-80.

Gamal M. Analytical review: analytical techniques for hyoscine N butyl bromide. Analyst, 2020; 145(6):2025-37.

Hosny NM. A review on: analysis of the first oral, direct factor Xa inhibitor; rivaroxaban. Microchem J, 2020; 159:105336.

Hostalek U, Koch EMW. Treatment of hypertension with a fixeddose combination of bisoprolol and amlodipine in daily practice: results of a multinational non-investigational study. Cardiovasc Disord Med, 2016; $1(3): 1-5$.

ICH. ICH guideline Q1A (R2). Stability testing of new drug substances and products. In International Conference on Harmonization, Geneva, Switzerland, 2003.

ICH. ICH guideline Q2A (R1). Validation of analytical procedures: text and methodology. In International Conference on Harmonization, Geneva, Switzerland, 2005.

Indian Pharmacopoeia. Government of India, Ministry of Health and Family Welfare, Indian Pharmacopoeia Commission, Gaziabad, India,
Mohammed F, Guillaume D, Warland J, Abdulwali N. Analytical methods to detect adulteration of argan oil: a critical review. Microchem J, 2021; 168:106501.

Pant S, Pal K. Development and validation of a simultaneous HPLC method for assay and dissolution of bisoprolol fumarate and amlodipine besylate in pharmaceutical Dosage. Res J Pharm Dos Forms Technol, 2012; 4(1):62-6.

Patil V, Devdhe S, Kale S, Kawade S, Pati R. Development and validation of new RP-HPLC method for the estimation of amlodipine besylate and bisoprolol fumarate in bulk and tablet dosage form. J Indian Chem Soc, 2014; 91(3):373-9.

Patil VS, Talele AN, Narkhede SB. Development and validation of chromatographic and spectrophotometric method for simultaneous estimation of amlodipine besilate and bisoprolol fumarate in tablet dosage form. European J Biomed Pharm Sci, 2017; 4(4):502-14.

Pena-Pereira F, Wojnowski W, Tobiszewski M. AGREEAnalytical GREEnness metric approach and software. Anal Chem, 2020; 92(14):10076-82.

Thakur A, Mishra B, Mahata PP. Pharmaceutical impurities: a review. Int J Pharm Chem, 2015; 5:232-9.

United State Pharmacopeia. United State Pharmacopeia USP 42-NF 37. US Pharmacopoeial Convention. Inc., Washington, DC,

Vora D, Kadav A. Development and validation of a simultaneous HPLC method for estimation of bisoprolol fumarate and amlodipine besylate from tablets. Indian J Pharm Sci, 2008; 70(4):542-6.

How to cite this article:

Gholve RB, Pekamwar SS, Kalyankar TM. Stabilityindicating RP-HPLC method development and validation for simultaneous estimation of bisoprolol fumarate and amlodipine besylate in bulk and in tablet dosage form. J Appl Pharm Sci, 2021; 11(12):121-134. 